\title{
Azadeh Kian. Le féminisme islamique en Iran : nouvelle forme d'assujettissement ou émergence de sujets agissants?
}

\section{Lucia Direnberger}

\section{(2) OpenEdition \\ 1 Journals}

\section{Édition électronique}

URL : http://journals.openedition.org/abstractairanica/41048

DOI : $10.4000 /$ abstractairanica.41048

ISSN : 1961-960X

Éditeur :

CNRS (UMR 7528 Mondes iraniens et indiens), Éditions de l'IFRI

\section{Édition imprimée}

Date de publication : 1 décembre 2013

ISSN : 0240-8910

Référence électronique

Lucia Direnberger, « Azadeh Kian. Le féminisme islamique en Iran : nouvelle forme d'assujettissement ou émergence de sujets agissants ? », Abstracta Iranica [En ligne], Volume 32-33 | 2013, document 459, mis en ligne le 01 juillet 2016, consulté le 27 septembre 2020. URL : http://journals.openedition.org/ abstractairanica/41048; DOI : https://doi.org/10.4000/abstractairanica.41048

Ce document a été généré automatiquement le 27 septembre 2020.

Tous droits réservés 


\title{
Azadeh Kian. Le féminisme islamique en Iran : nouvelle forme d'assujettissement ou émergence de sujets agissants?
}

\author{
Lucia Direnberger
}

\section{RÉFÉRENCE}

Azadeh Kian. « Le féminisme islamique en Iran : nouvelle forme d'assujettissement ou émergence de sujets agissants? ». Critique Internationale, $\mathrm{n}^{\circ} 46$, janvier mars 2010, $\mathrm{p}$. 45-66.

1 L'A. décrit les conditions d'émergence et les caractéristiques du féminisme islamique en Iran, qui se démarque du féminisme laïque par sa stratification sociale (classe moyennes modernes ou supérieures) et par sa référence au Coran pour revendiquer l'égalité homme/femme. Défiant le discours qui définit l'Islam comme incompatible avec la démocratie, le féminisme islamique témoigne de l'importance des transformations sociales et économiques ont traversé l'Iran depuis la Révolution Islamique.

2 L'A. dresse une typologie des militantes du féminisme islamique en fonction de leur génération, de leur niveau d'éducation et des modalités de leur engagement. Les féministes islamiques sont parvenues à se constituer en groupes de pression au sein des partis et participent à la diversification des structures politiques en Iran. Elles ont effectué un travail critique des interprétations discriminantes pour les femmes du Coran et des textes législatifs en vigueur comme le Code pénal.

3 La déception de la présidence de Hâtamī et la radicalisation du régime après Aḥmadīnežād ont poussé les féministes islamiques à se rapprocher des féministes laïques. L'élection présidentielle de 2009 illustre cette coalition islamique et féministe 
qui agit contre les discriminations faites aux femmes et contre le renforcement du système conservateur.

\section{AUTEURS}

\section{LUCIA DIRENBERGER}

Paris 